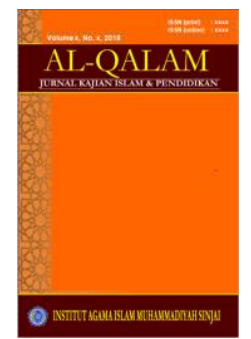

\title{
AL-QALAM
}

Jurnal Kajian Islam \& Pendidikan

Volume 07 No 022015

ISSN (print) : 1858-4152

ISSN (online) : 2715-5684

Homepage : http://journal.iaimsinjai.ac.id/index.php/al-qalam

\section{KEBIJAKAN PENGEMBANGAN MADRASAH; SEBUAH WACANA STRATEGI REPOSISI}

\author{
Oleh: Umar \\ $* * *$
}

\begin{abstract}
Abstrak
Di Indonesia lembaga pendidikan Islam (madrasah) merupakan lembaga pendidikan kedua setelah pesantren. Pada historisnya lembaga pendidikan Islam ini mengalami dinamika sekaligus polemik yang sangat panjang sejak pra kemerdekaan hingga era pasca reformasi saat ini. Problematika yang dihadapi lembaga pendidikan Islam khususnya madrasah dinilai sangat terkait dengan kebijakan yang belum sepenuhnya berpihak pada pola pengembangan madrasah yang cenderung eksklusif dibanding dengan system pendidikan umum sehingga berimplikasi pada out put yang dihasilkan belum menempati posisi yang setaraf dengan yang lainnya, pada hal pendidikan Islam madrasah di era globalisasi penting melakukan reposisi secara sistemik, empiris-paradigmatik. Strategi reposisi ini dapat dilakukan dengan melihat bentuk-bentuk kebijakan dan sistemnya sekaligus diarahkan pada pola pengembangan yang lebih kompetitif di era global, inklusif, dan substansif dalam peranannya.
\end{abstract}

Kata Kunci: Kebijakan, Madrasah, Strategi Reposisi.

\section{PENDAHULUAN}

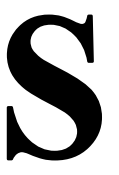

alah satu institusi pendidikan formal yang bercirikan Islam di Indonesia adalah madrasah. Madrasah yang lahir dari rahim pesantren dan telah berkembang hingga saat ini. Sedangkan pesantren merupakan system pendidikan yang telah hadir dan tertua jauh sebelum Indonesia merdeka. Dalam konteks sejarah pendidikan bangsa Indonesia hingga kini peran pesantren dan madrasah sangat memberikan kontribusi yang besar bagi pembangunan manusia Indonesia yang utuh. System pendidikan yang bercirikan Islam seperti halnya madrasah merupakan salah satu dambaan masyarakat Indonesia yang mayoritas penduduknya beragama Islam disamping system pendidikan umum.

\footnotetext{
${ }^{*}$ Dosen STAI Muhammadiyah Sinjai
} 
Kemunculan madrasah dipandang menjadi salah satu indikator penting bagi perkembangan positif kemajuan prestasi budaya umat Islam, mengingat realitas pendidikan, sebagaimana terlihat pada fenomena madrasah yang sedemikian maju, adalah cerminan dari keunggulan capaian keilmuan, intelektual dan kultural. Maka dari itu, timbul kebanggaan terhadap madrasah, karena lembaga ini mempunyai citra "ekslusif" dalam penilaian masyarakat. Akan tetapi kini eksistensi madrasah di tanah air nampaknya jauh berbeda dengan prestasi gemilang sejarah madrasah dimasa lalu tersebut. ${ }^{1}$

Potensi madrasah dalam pembangunan manusia Indonesia yang utuh sangat besar dan selalu diperhitungkan oleh masyarakat modern, system pendidikan ini merupakan bentuk kemajuan dari tradisi pesantren yang tetap perlu pengembangan seiring dengan kemajuan zaman dan tuntutan globalisasi, hal ini disebabkan karena madrasah pun memiliki kompleksitas dan dinamika problem yang dihadapi. Disisi lain perhatian pemerintah terhadap institusi dan system pendidikan di Indonesia seolah hanya sepihak pada pendidikan umum jika dibanding dengan lembaga pendidikan keilmuan yang berbasiskan keislaman seperti madrasah.

Eksistensi madrasah hingga kini tetap seiring dengan pembangunan dan pendidikan nasional. Sebagai bagian dari system pendidikan nasional yang dikelolah oleh Kementerian Agama juga tetap berada pada tatanan fungsinya yang mencerdaskan anak bangsa. Hal ini tetap relevan dengan tujuan dan cita-cita pendidikan nasional kita. $^{2}$ Dengan demikian kebijakan penyelenggaraan pendidikan madrasah ini untuk pengembangan mutu pendidikan berpijak pada Undang-Undang dan Peraturan Pemerintah yang diantaranya adalah UUSPN No. 20 Tahun 2003 dan keputusan Menteri Agama RI diantaranya adalah nomor 369

\footnotetext{
${ }^{1}$ Mahmud Arif, Sketsa Sejarah, Geliat, dan Dinamika Peran Madrasah dalam Merespon Tantangan Pendidika Islam (Dilema Madrasah dalam Kancah Pendidikan dan Peran Kontributif Madrasah Berbasis Pesantren). Eds. Prof. Dr. Nizar Ali, M.Ag dan Dr. H. Sumedi, M.Ag. dalam Ontologi Pendidikan Islam, (Yogyakarta, Program Pascasarjana UIN Sunan Kalijaga kerjasama Penerbit Idea Press, 2010), hlm.143.

${ }^{2}$ Lihat lebih lanjut fungsi dan tujuan pendidikan nasional, pasal 3 dalam Undang-Undang No. 20 Tahun 2003 tentang Sisdiknas, (Tambahan Lembaran Negara Republik Indonesia Nomor 4301), diundangkan di Jakarta pada tanggal 8 Juli 2003.
} 


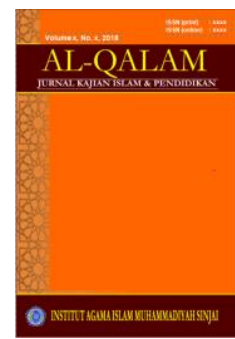

\section{AL-QALAM}

Jurnal Kajian Islam \& Pendidikan

Volume 07 No 022015

ISSN (print) : 1858-4152

ISSN (online) : 2715-5684

Homepage : http://journal.iaimsinjai.ac.id/index.php/al-qalam

tahun 1993 tentang Madrasah Tsanawiyah, nomor 370 Tahun 1993 tentang madrasah Aliyah.

Madrasah sebagai komponen pendidikan nasional tidak perlu vakum dalam satu situasi (ruang dan waktu) tetapi memerlukan pembaharuan seiring dengan tuntutan globalisasi. Pengembangan madrasah dalam era globalisasi ini bukanlah sesuatu yang sederhana. Aturan yang lahir sebagai kebijakan yang normatif tentunya menuntut pula pengembangan system madrasah yang tak hanya pada aspek eksistensi keislaman yang menjadi ciri khasnya. Banyaknya aspek dalam pendidikan Islam (madrasah) perlu mendapat perhatian dari berbagai kalangan khususnya pemerintah, praktisi dan akademisi pendidikan guna mengembangkan system pendidikan terutama madrasah yang terkait persoalan terbengkalainya mutu (kendati banyak pengakuan dari berbagai kalangan akan mutunya), belum lagi persoalan yang diasumsikan oleh masyarakat kita bahwa lembaga dan system pendidikan madrasah belum bisa menyaingi pendidikan umum. Hasan Langgulung berpendapat bahwa satu hal yang perlu diingat disini bahwa dalam mengupas mengenai pendidikan Islam disini tidak dibatasi pada persekolahan saja, walaupun tradisi sekolah (madrasah) itu adalah salah satu ciri utama sejarah pendidikan Islam. ${ }^{3}$

Berangkat dari uraian di atas, dapat ditelaah rumusan permasalahan yang perlu dilakukan eksplorasi mendalam melalui pendekatan ideologis dan historis. Rumusan masalah tersebut yaitu, (1) Seperti apa sejarah kemunculan madrasah?, (2) Bagaimana tinjauan historis dan perkembangan madrasah di Indonesia?, (3) Bagaimana kebijakan pemerintah dan problematika madrasah di Indonesia?, (4) Bagaimana langkah-langkah reposisi pengembangan madrasah?.

Hasil eksplorasi permasalahan tersebut tentunya diharapkan untuk memberikan informasi dan pemahaman bagi pemegang kebijakan pendidikan dan unsur-unsur yang terkait dalam pengelolaan dan pengembangan pendidikan khususnya pengembangan madrasah dalam skala makro sekaligus sifatnya

\footnotetext{
${ }^{3}$ Hasan Langgulung, Asas-Asas Pendidikan Islam, (Jakarta: Al-Husna Zikra, 2000), hlm. viii.
} 
otokritik plus produktif dengan mengambil peran menempatkan diri disela-sela kekosongan ruang terhadap polemik dan dinamika pendidikan di Indonesia. Tidak dapat dipungkiri persoalan kebijakan dalam pendidikan maupun pengembangan sistem pendidikan adalah persoalan politik.

\section{PEMBAHASAN}

\section{A. Sejarah Kemunculan Madrasah}

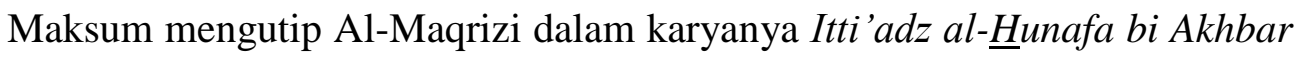
al Aimmah al-Fatimiyyin al-Khulafa, mengemukakan bahwa madrasah merupakan prestasi abad kelima hijriyah. Madrasah-madrasah yang timbul dalam Islam, tidak dikenal pada masa-masa sahabat dan tabi'in, melainkan sesuatu yang baru setelah 400 tahun sesudah hijriyah, lebih lanjut Umar Rida Kahhalah dalam Jaula fi Rubu' al-Tarbiyah wa al-Ta'lim, mengemukakan bahwa madrasah pertama yang didirikan pada abad kelima Hijriyah (ke-11 Masehi) itu ialah Nizamiyah yang didirikan pada tahun $457 \mathrm{H}$ oleh Nizam al-Mulk ${ }^{4}$ di Baghdad.

Dilain hal penulis kontemporer menyatakan bahwa kata "madrasah" belum dijumpai pada sumber-sumber sejarah hingga kira-kira abad ke-4 masehi. Akan tetapi banyak bukti yang signifikan justru menunjukkan bahwa madrasah telah berdiri sejak abad ke empat hijriyah dan dihubungkan dengan penduduk Naisabur.5 Dalam KBBI kata "madrasah" adalah sekolah atau perguruan (biasanya yang berdasarkan agama Islam) ${ }^{\mathbf{6}}$, Kelahiran lembaga pendidikan (madrasah) memberikan corak yang mewarnai eksistensi Islam dimasa

${ }^{4}$ Maksum, Madrasah Sejarah dan Perkembangannya, (Jakarta,Logos Wacana Ilmu,1999), hlm. 60. Menurut Ahmad Syalaby, sekolah-sekolah Nizhamul Mulk termasyhur di dunia. Tidak ada suatu negeri pun yang disitu tidak berdiri sekolah Nizhamul Mulk, Nizhamul Mulk mendirikan sekolah-sekolahnya yang besar yaitu di Baghdad, Balch, Nashabur, Harat, Isfahan, Basrah, Merw, Amul dan Mosul, ada orang yang mengatakatan bahwa Nizhamul Mulk mendirikan sebuah sekolah pada tiap-tiap negeri di Irak dan Khurasan. Sekolah-sekolah yang didirikan oleh Nizhamul Mulk mempunyai kedudukan yang tinggi dalam pandangan kaum muslimin. Lihat, Ahmad Syalaby, Sedjarah Pendidikan Islam, Ter. Muchtar Yahya \& Sanusi Latief, (Jakarta: Bulan Bintang, t.t), hlm. 111-112.

${ }^{5}$ Ibid,

${ }^{6}$ Suharso \& Ana Retnoningsih, Kamus Besar Bahasa Indonesia, Edisi Lux, (Semarang: CV. Widia Karya, 2011), hlm. 302. 


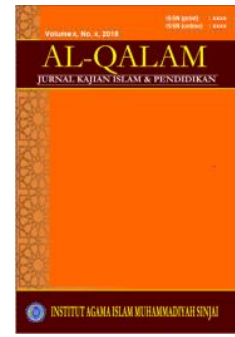

\section{AL-QALAM}

Jurnal Kajian Islam \& Pendidikan

Volume 07 No 022015

ISSN (print) : 1858-4152

ISSN (online) : 2715-5684

Homepage : http://journal.iaimsinjai.ac.id/index.php/al-qalam

kejayaannya hingga sekarang, dimana peranannya yang sangat vital dalam pengembangan ilmu pengetahuan yang berbasiskan keislaman maupun bidang ilmu lainnya. Abdullah Idi dan Toto Suharto ${ }^{7}$ mengemukakan bahwa bahwa kelahiran madrasah menjadi lambang kebangkitan sistem pendidikan Islam.

\section{B. Sekilas Historis Madrasah dan Perkembangannya di Indonesia}

di Indonesia kata "madrasah" digunakan sebagai nama sebuah sistem pendidikan Islam yang sudah menggunakan metode klasikal dan berada dibawah naungan Kementerian Agama. Diluar mata pelajaran agama, sistem pendidikan di madrasah hampir sama dengan sistem pendidikan umum. Dalam sistem pendidikan madrasah ini dikenal Madrasah Ibtidaiyah setingkat dengan Sekolah Dasar, Madrasah Tsanawiyah setingkat dengan Sekolah Menengah pertama, Madrasah Aliyah setingkat dengan SMU (Sekolah Menengah Umum). ${ }^{\mathbf{8}}$ Madrasah tidak serta merta dipahami sebagai sekolah melainkan diberi konotasi yang lebih spesifik yaitu "sekolah agama" tempat dimana anak-anak didik menempuh pembelajaran hal-ikhwal atau seluk-beluk agama dan keagamaan (Islam). ${ }^{9}$ Pemaknaan kata "madrasah" untuk menyebut sekolah Islam dilatari munculnya gagasan modernisasi pendidikan Islam oleh beberapa organisasi "modernis", seperti Jami'at Khair, al-Irsyad, Muhammadiyah dan lain-lain dengan mengadopsi sistem pendidikan kolonial Belanda. ${ }^{10}$

Perkembangan pendidikan Islam (madrasah) di Indonesia melalui 4 masa yaitu:

\section{Madrasah Pada Masa Pra-Kemerdekaan}

Menurut Malik Fadjar dalam Abdurrachman Mas'ud mengemukakan bahwa Madrasah sebagai lembaga pendidikan Islam di Indonesia relatif lebih muda dibanding pesantren. Ia lahir pada abad ke-20 dengan munculnya

${ }^{7}$ Abdullah Idi \& Toto Suharto, Revitalisasi Pendidikan Islam, (Yogyakarta: Tiara Wacana, 2006), hlm.20.

${ }^{8}$ S. Yunanto, et.al, Pendidikan Islam di Asia Tenggara dan di Asia Selatan (Keragaman, Permasalahan dan Strategi), (Jakarta:The RIDEP Institut kerjasama Friedrich Ebert Stiftung,2005), hlm. 21.

${ }^{9}$ Ara Hidayat \& Imam Machali, Pengelolaan Pendidikan (Konsep, Prinsip, dan Aplikasi dalam Mengelolah Sekolah dan Madrasah, (Yogyakarta: Kaukaba, 2012), hlm. 128.

${ }^{10} \mathrm{~S}$. Yunanto, et.al, Pendidikan., hlm. 22. 
Madrasah Mamba'ul Ulum Kerajaan Surakarta pada tahun 1905 dan sekolah Adabiyah yang didirikan oleh Syekh Abdullah Ahmad di Sumatera Barat pada tahun 1909.11

Terlepas dari kenyataan historisnya, eksistensi madrasah dalam tradisi pendidikan Islam di Indonesia tergolong fenomena modern yaitu mulai sekitar awal abad ke-20. ${ }^{12}$ Kehadirannya di Indonesia merupakan tahapan pembaharuan dan pengembangan lembaga pendidikan yang tak hanya terpusat pada tradisi pengajaran ilmu-ilmu Islam. Gerakan pembaharuan lembaga pendidikan Islam ini yang diawali oleh para tokoh intelektual Islam yang sebagian besar disambut baik oleh masyarakat Islam nusantara. System pendidikan Islam madrasah yang identitasnya telah diterapkan hingga sekarang, tetap bertahan kendati beragam tantangan dan kendala sekaligus intervensi yang dihadapi terutama pada masa-masa penjajahan kolonial Belanda.

Kemunculan madrasah merupakan realisasi upaya pembaharuan system pendidikan Islam yang telah ada. Pembaharuan tersebut meliputi tiga hal yaitu: (1) upaya penyempurnaan system pesantren, (2) penyesuaian terhadap system Barat, (3) menjembatani antara system pendidikan tradisional Pesantren dan system pendidikan modern barat. ${ }^{13}$ Senada dengan pendapat Maksum, bahwa latar belakang pertumbuhan madrasah di Indonesia dapat dikembalikan pada dua situasi yaitu adanya gerakan pembaharuan Islam di

${ }^{11}$ Abdurrachman Mas'ud, dkk, Dinamika Pesantren dan Madrasah, eds. Ismail SM, dkk, (Semarang: Fakultas Tarbiyah IAIN Walisongo bekerja sama Pustaka Pelajar, Yogyakarta, 2002), hlm.226.

${ }^{12}$ Buku-buku sejarah pendidikan Islam di Indonesia sejauh ini agaknya tidak pernah menginformasikan adanya lembaga pendidikan yang disebut madrasah pada masa-masa awal penyebaran dan perkembangan Islam di Nusantara. Evolusi kelembagaan pendidikan diwilayah ini bermula dari pesantren, madrasah, dan kemudian sekolah. Sebagai bahan perbandingan, di Malaysia perkembangan pendidikan Islam berawal dari majelis pengajaran al-Qur'an, pondok pesantren, dan akhirnya madrasah. Dalam hal ini diakui bahwa madrasah baru muncul pada awal abad ke-20 sebagai akibat dari perasaan tidak puas terhadap system pondok yang terlalu sempit dan terbatas pengajaran ilmu-ilmu fard 'ain. Rosnani Hashim dalam Maksum, Educational Dualism: Impication for Theory and Practice, (Oxford: Oxford University Press, 1996) yang pada awalnya merupakan disertasi penulisnya pada University of Florida, Gainesville, 1995. Lihat Maksum, Madrasah., Ibid, hlm. 79-80

${ }^{13}$ Abdurrachman Mas'ud, dkk, Dinamika., hlm. xxi. 


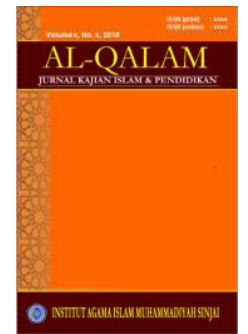

\section{AL-QALAM}

Jurnal Kajian Islam \& Pendidikan

Volume 07 No 022015

ISSN (print) : 1858-4152

ISSN (online) : 2715-5684

Homepage : http://journal.iaimsinjai.ac.id/index.php/al-qalam

Indonesia dan adanya respon pendidikan Islam terhadap kebijakan pendidikan Hindia Belanda. ${ }^{14}$ Dari pembaruan tersebut dapat disimpulkan bahwa kehadiran madrasah disebabkan pesantren dirasakan kurang memenuhi kebutuhan pendidikan Islam dan kemampuan pragmatis masyarakat. Disisi lain kekhawatiran akan perkembangan pendidikan barat (system pendidikan Belanda) yang sekuler guna menyeimbangkan pemikiran sekularisme.

Seiring dengan perkembangan dan menjawab kebutuhan masyarakat akan pentingnya lembaga pendidikan khususnya lembaga pendidikan Islam yang tidak hanya terfokus pada pendidikan keislaman semata, maka lembaga pendidikan pesantren secara perlahan dikonversi baik metode maupun sistemnya menjadi pendidikan madrasah. Dengan demikian visi pesantren tetap menjadi bagian dari visi yang ada pada pendidikan madrasah. Menurut Karel A. Steenbrink bahwa lembaga agama itu memang berkembang ke arah yang memang mirip dengan sistem sekolah. Namun iya berbeda karena lebih menekankan pengajaran agama. Sistem pendidikan seperti ini disebut dengan sistem pendidikan madrasah, karena pengajaran Qur'an dan kitab yang sudah memakai sistem kelas ini di Indonesia pada umumnya disebut madrasah baik yang sudah ditambah pelajaran umum maupun yang 100 persen agama. ${ }^{\mathbf{1 5}}$

\section{Madrasah pada Masa Orde Lama}

Diawal tulisan ini dikemukakan bahwa lembaga pendidikan Islam di Indonesia yang lebih tua yaitu pesantren yang telah ada jauh sebelum kemerdekaan bangsa Indonesia, lembaga pendidikan madrasah sebagai embrio dari pesantren pun telah hadir sejak itu. Madrasah dianggap sebagai perkembangan lanjut atau pembaharuan dari lembaga pendidikan pesantren dan surau. ${ }^{\mathbf{1 6}}$ Berselang pasca kemerdekaan-pemerintahan Orde Lama peranan madrasah juga menyesuaikan kelembagaannya dengan kebutuhan masyarakat.

${ }^{14}$ Maksum, Madrasah., hlm. 82.

${ }^{15}$ Karel A. Steenbrink, Pesantren Madrasah Sekolah (Pendidikan Islam dalam Kurun Moderen), (Jakarta: Darma Aksara Perkasa, 1986), hlm.88.

${ }^{16}$ Maksum, Madrasah., hlm.80 
Namun lembaga pendidikan Islam madrasah ini belum begitu berkembang baik kebijakan yang berpihak untuk pengembangan maupun jumlahnya diwilayah tanah air.

Dilain hal menurut Zuhairini dalam Imam Machali bahwa perkembangan pendidikan Islam pada masa Orde Lama erat kaitannya dengan peran Departemen Agama yang secara intensif memperjuangkan politik pendidikan Islam. Orientasi Depag dalam bidang pendidikan Islam berdasarkan aspirasi umat Islam adalah agar pendidikan agama diajarkan di sekolah-sekolah disamping pengembangan madrasah itu sendiri. Kebijakan pendidikan Islam semakin signifikan sejak Depag mendapat tanggung jawab membina dan pengembangan pendidikan agama di lembaga-lembaga pendidikan. ${ }^{17}$ Selain itu tujuan utama dari kebijaksanaan Departemen Agama adalah untuk menghapuskan perbedaan antara sistem sekolah dan madrasah. ${ }^{18}$

Selama 20 tahun pemerintahan Orde Lama praksis bergelut pada persoalan politik dan kelembagaan negara serta mengabaikan banyak aspek kehidupan lainnya, termasuk dalam hal pendidikan. Namun terdapat sisi menarik terkait dengan pendidikan Islam di era tersebut yaitu dengan berdirinya Sekolah Tinggi Islam di Jakarta pada tanggal 8 Juli 1946 oleh Badan Pengurus Sekolah Tinggi Islam (STI) yang kemudian hari ketika itu pemerintahan pindah ke Yogyakarta, STI juga pindah dan dikenal dengan nama Universitas Islam Indonesia (UII). ${ }^{19}$ Kendati demikian bangsa Indonesia tetap menilai hal ini menandai bahwa pemerintah ketika itu sama sekali belum terfokus pada sektor pendidikan bagi anak-anak bangsa. Pada tahap selanjutnya menjelang pemerintahan Orde Baru telah muncul tanda peningkatan yang signifikan dengan berdirinya lembaga-lembaga pendidikan Islam diberbagai wilayah di Nusantara.

${ }^{17}$ Ara Hidayat \& Imam Machali, Pengelolaan., hlm. 136.

${ }^{18}$ Karel A. Steenbrink, Pesantren., hlm. 88.

${ }^{19}$ Eko Susilo, dkk. Politik Pendidikan Nasional, edt. Syahridlo dan Sutarman, (Yogyakarta, Kopertais Wilayah III Daerah Istimewa Yogyakarta UIN Sunan Kalijaga,2011), hlm. 270. Lihat juga, Amin Abdullah, Pendidikan dan Upaya Mencerdaskan Bangsa, Paradigma Baru Pendidikan, (Jakarta: IISEP), hlm.42-43. 


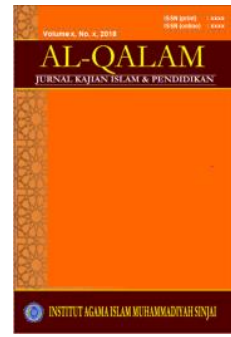

\section{AL-QALAM}

Jurnal Kajian Islam \& Pendidikan

Volume 07 No 022015

ISSN (print) : 1858-4152

ISSN (online) : 2715-5684

Homepage : http://journal.iaimsinjai.ac.id/index.php/al-qalam

Jika ditinjau dari dari beberapa aspek historisnya ketika orde lama, boleh dikatakan bahwa madrasah khususnya dibeberapa daerah terutama di pulau Jawa memang mendapat perhatian namun masih sebatas pengembangan politik pendidikan Islam, pengembangan ini belum menunjukkan pemerataan yang signifikan ke berbagai wilayah di tanah air, yang mendominasi hanyalah pendidikan Islam pesantren namun lambat laun pendidikan madrasah ini pun dikenal oleh masyarakat Indonesia menjelang pemerintahan orde baru.

\section{Madrasah pada Masa Orde Baru}

Memasuki masa Orde Baru kebijakan penguasa dalam segala sektor turut mempengaruhi perkembangan pendidikan, terutama pada lembaga pendidikan Islam. Madrasah pun dinilai berkembang dan tetap menyandang indentitas sebagai lembaga pendidikan Islam. Kebijakan pemerintah terhadap madrasah dalam hal ini adalah adanya Surat Keputusan Bersama (SKB) 3 Menteri, yaitu Menteri Pendidikan dan Kebudayaan No. 037/U/1975, Menteri Agama No. 6 Tahun 1975, dan Menteri dalam Negeri No. 36 Tahun 1975 tentang "Peningkatan Mutu Pendidikan pada Madrasah" dan SK Bersama Dua Menteri, yaitu: Menteri Pendidikan dan Kebudayaan No. 0299/U/1984 dan Menteri Agama No. 45 Tahun 1984 "Tentang Peraturan Pembakuan Kurikulum Sekolah Umum dan Madrasah”. Namun sebelum dikeluarkannya SKB 3 Menteri tersebut diatas madrasah mengalami perubahan nama dan struktur menjadi madrasah negeri terutama Madrasah Tsanawiyah (MTs) dan Madrasah Aliyah (MA) pada awal pemerintahan Orde Baru.

Abdurrachman Mas'ud mengemukakan, keputusan bersama tersebut dinilai sebagai strategi dan lengkah positif terhadap peningkatan mutu pendidikan madrasah dalam hal status, persamaan ijazah dengan sekolah umum maupun dari segi kurikulumnya. Didalam salah satu diktum pertimbangan SKB tiga menteri disebutkan perlunya diambil langkah-langkah untuk meningkatkan mutu pendidikan pada madrasah agar lulusan dari madrasah dapat melanjutkan atau pindah ke sekolah-sekolah umum dari 
sekolah dasar sampai perguruan tinggi. ${ }^{20}$ Lebih lanjut Maksum, SKB tiga Menteri ini dapat dipandang sebagai pengakuan yang lebih nyata terhadap eksistensi madrasah dan sekaligus merupakan langkah strategis menuju tahapan integrasi madrasah ke dalam Sistem Pendidikan Nasional yang tuntas. $^{21}$

Imbas lain diberlakukannya SKB 3 menteri yakni konsep penyetaraan pendidikan madrasah dengan sekolah umum pada akhirnya menimbulkan konsekwensi mengenai pendidikan agama yang proporsinya hanya $30 \%$ dan pendidikan umum $70 \%$ yang sebelumnya pendidikan agama adalah $60 \%$ dan pendidikan umum sebanyak $40 \%$. Langkah tersebut sebagai salah satu bentuk memodernisasi madrasah, hal ini banyak yang mengindikasikan bahwa penentuan proporsi yang agak berlebihan menimbulkan kekhawatiran akan adanya tendensi kearah pendidikan yang bercirikan pendidikan sekuler modern hingga berpotensi mengarahkan lembaga madrasah yang lepas dari ciri khasnya yaitu nilai-nilai keislaman.

\section{Pada Masa Reformasi Hingga Sekarang}

Pada era orde reformasi, kebijakan pemerintah yang sangat berpengaruh terhadap pendidikan di Indonesia, yakni dengan pergantian Undang-Undang Sistem Pendidikan Nasional Nomor 2 tahun 1989 menjadi Undang-Undang Sistem Pendidikan Nasional Nomor 20 Tahun 2003, hal ini telah memberikan peluang yang sama kepada lembaga pendidikan Islam (madrasah) selain sekolah umum berciri khas Islam untuk mendapat pengakuan, penghargaan.

Imam Machali mengutip Ali Masykur dalam tulisannya menjelaskan bahwa Undang-undang terbaru ini (UUSPN nomor 20 Tahun 2003) sudah cukup akomodatif dan representatif bila dibandingkan dengan UU No. 12 tahun 1989, sebab selama ini ada pandangan dan reaksi masyarakat yang menyoroti dasar filsafat pendidikan, tujuan pendidikan yang dianggap tidak

\footnotetext{
${ }^{20}$ Abdurrachman Mas'ud, dkk, Dinamika., hlm.227.

${ }^{21}$ Maksum, Madrasah., hlm.151.
} 


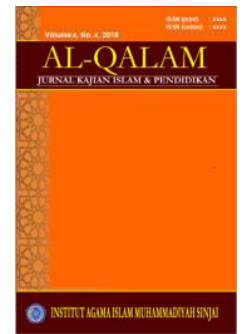

AL-QALAM

Jurnal Kajian Islam \& Pendidikan

Volume 07 No 022015

ISSN (print) : 1858-4152

ISSN (online) : 2715-5684

Homepage : http://journal.iaimsinjai.ac.id/index.php/al-qalam

mencerdaskan, campur tangan pemerintah, aturan yang tidak demokratis dan memihak agama tertentu. ${ }^{22}$

Dengan diberlakukannya UUSPN nomor 20 Tahun 2003 menjadikan pendidikan Islam (madrasah) semakin diakui dan turut berperan dalam peningkatan kualitas generasi bangsa, selain itu pertumbuhan dan perkembangan pendidikan Islam (madrasah) akan lebih baik dibandingkan dengan kebijakan-kebijakan sebelumnya. ${ }^{23}$ Dengan diperkuat oleh UU No. 22 tahun 1999 tentang "otonomi daerah", hal ini telah memberikan ruang terbuka yang lebih luas untuk proses pengembangan pendidikan Islam madrasah kearah yang lebih maju seiring tantangan globalisasi.

Pada pasca reformasi ${ }^{24}$ amanah yang telah tertuang dalam UndangUndang yang terkait kebijakan pengembangan pendidikan belumlah dapat dimaksimalkan pemerintah sesuai harapan dan cita-cita bangsa khususnya umat Islam dalam pengembangan pendidikan Islam (madrasah). Perhatian pemerintah dalam hal ini masih belum memuaskan semua pihak, adanya perbedaan pemahaman tentang pendidikan Islam dikalangan pemerintah sehingga kebijakan yang muncul hanya berdasarkan cara pandang masingmasing. Tataran praktis ini pun kian menimbulkan ketidakadilan yang belum berujung.

Belum maksimalnya keberpihakan kebijakan pemerintah terhadap pendidikan madrasah yang dirasakan hingga hari ini, kendati telah dikenal adanya otonomi daerah dan otonomi sekolah sebagai desentralisasi pendidikan yang konsepnya memberikan ruang terbuka pengembangan pendidikan yang lebih berkualitas, namun system otonomi tersebut seolah sebatas wacana. Sebagai potret sederhana "kurikulum tetap keputusan dan milik pemerintah pusat",-cukup dinamis sebab dalam kurun waktu sepuluh tahun terakhir terjadi

\footnotetext{
${ }^{22}$ Imam Machali, Kebijakan Pendidikan Islam dari Masa Ke Masa, Dari Kebijakan Diskriminatif Menuju Kebijakan Berkeadilan, dalam Website: http://www.imammachali.com/berita-138-.html, Diakses, 2 Maret 2013, pukul 17.00 WIB.

${ }^{23}$ Ara Hidayat \& Imam Machali, Pengelolaan., hlm. 140.

${ }^{24}$ Era pemerintahan presiden SBY (pada Kabinet Indonesia Bersatu jilid I dan Kabinet Indonesia Bersatu jilid II).
} 
tiga pergantian kurikulum, berikut aturan-aturan lainnya. Ragam serta pergantian kurikulum yang diberlakukan dalam skala waktu tertentu dari Kurikulum Berbasis Kompetensi (KBK) dan Kurikulum Tingkat Satuan Pendidikan (KTSP) belum pula menunjukkan capaian yang serius, menyusul kurikulum 2013 yang pernah diberlakukan secara tergesa-gesa dan (dalam tahap uji public) namun akhirnya kembali ke KTSP hingga menimbulkan ragam pertanyaan baik penggunaan maupun substansinya. Hal ini tentunya kebijakan dimasa-masa yang akan datang diindikasikan akan memiliki pengaruh yang luar biasa entah keberpihakan atau pun malah menyempitkan ruang terhadap lembaga pendidikan Islam (madrasah). Tentu kebijakan terhadap pendidikan umum dan pendidikan Islam (madrasah) khususnya akan semakin kompleks dimasa-masa yang akan datang.

\section{Dari Kebijakan Hingga Problematika Madrasah di Indonesia Masa Kini}

Sejak kehadiran madrasah di bumi nusantara hingga era global sekarang ini kebijakan pemerintah terhadap eksistensi madrasah masih dinilai belum berpihak maksimal terhadap pengembangan SDM yang berbasiskan Islam yang notabene negara Indonesia berpenduduk muslim terbesar. Sejak kemerdekaan hingga pasca reformasi madrasah tetap memberikan peran yang maksimal terhadap perkembangan dan kemajuan bangsa, namun benar adanya penilaian dari berbagai pihak bahwa peranan dan jasa besar tersebut dengan kebijakan pemerintah terhadap lembaga pendidikan Islam madrasah dirasakan tidaklah sebanding.

Sepanjang sejarahnya persoalan-persoalan yang muncul justru menantikan sentuhan-sentuhan pemikiran dan solutif tepat sesuai perkembangan dan kompetisi global saat ini. Persoalan utama yang dihadapi oleh madrasah selalu menjadi topik perbincangan diberbagai kalangan adalah umumnya pada persoalan mutu yang dimiliki terutama pada madrasahmadrasah yang berstatus swasta. 


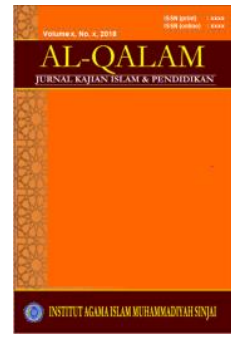

\section{AL-QALAM}

Jurnal Kajian Islam \& Pendidikan

Volume 07 No 022015

ISSN (print) : 1858-4152

ISSN (online) : 2715-5684

Homepage : http://journal.iaimsinjai.ac.id/index.php/al-qalam

Problematika pendidikan madrasah di Indonesia pada umumnya sebagaimana yang dikemukakan Yusuf Hasyim mengutip Philip H. Coombs dalam bukunya “What is Educational Planning?”, paling tidak ada 4 tahapan permasalahan yang dilewati dunia pendidikan, yaitu, ${ }^{25}$

1. Tahap rekonstruksi, pendidikan dihadapkan pada permasalahan pengkondisian otoritas pendidikan, desentralisasi pendidikan, serta perencanaan fasilitas pendidikan.

2. Tahap Ketenagakerjaan/Penyiapan SDM, pendidikan dihadapkan pada penyiapan tenaga kerja yang terampil dan cakap (tenaga ahli).

3. Tahap Perluasan/Pengembangan pendidikan meliputi pengembangan kurikulum, metode, pengujian, demokrasi pendidikan, serta adaptasi sistem pendidikan dan ekonomi.

4. Tahap Inovasi, berhubungan dengan perencanaan pendidikan dan strategistrategi pengembangan.

Dengan adanya kebijakan SKB 3 Menteri seperti yang tersebut di awal memunculkan pula polemik yang dihadapkan pada pilihan-pilihan yang sulit. yaitu, Pertama, disatu sisi ia harus tetap mempertahankan mutu pendidikan agama yang menjadi ciri khasnya; Kedua, disisi lain dituntut untuk mampu menyelenggarakan pendidikan umum yang secara baik dan berkualitas supaya sejajar dengan sekolah umum. Kegagalan madrasah dalam memikul tersebut hanya akan memperkuat anggapan orang bahwa madrasah adalah semacam "sekolah serba tanggung". ${ }^{26}$ Azyumardi Azra mengemukakan bahwa tugas yang dipikul madrasah pada akhirnya, adalah mewujukan anak didik yang memiliki pengetahuan keislaman dan ilmu-ilmu lain; dan sekaligus dapat mengamalkan pengetahuan yang mereka miliki. Dengan begitu, mereka selanjutnya dapat tumbuh menjadi anggota masyarakat Muslim Indonesia

25 Yusuf Hasyim, Kebijakan Otonomi Daerah dan Implikasinya Terhadap Pendidikan Madrasah, dalam Website: http://gurubangsaku.wordpress.com,2012/04/27/, diakses, 2 Maret 2013. Pukul, 17.15 WIB. 15.

${ }^{26}$ H. Ary Gunawan, Kebijakan Kebijakan Pendidikan, (Jakarta: Rineka Cipta, 1995), hlm. 
yang beriman dan bertakwa kepada Allah SWT. ${ }^{27}$ Selain dituntut mampu mengembangkan tugas pendidikan, dituntut pula untuk menunaikan tugas utamanya dalam pendidikan keagamaan. Belum lagi tugas utama tadi dijalankan dengan baik tugas pendidikan keagamaan yang dulu melatarbelakangi kelahiran madrasah pun belakangan ini kian senter disorot, seiring memperihatinkannya gejala dekadensi moral generasi muda. ${ }^{28}$

Pada persoalan lain, kesenjangan antara madrasah swasta dan madrasah negeri yang belum terselesaikan, perhatian pemerintah terkait masalah ini masih seolah jadi catatan yang tersimpan rapi. Sebagai implikasi kebijakan seakan memunculkan penilaian bagi masyarakat akan madrasah negeri yang mendapatkan perhatian lebih dari pemerintah. Mutu pendidikan yang relatif kurang terjamin dibandingkan mutu sekolah umum, hal ini disebabkan karena ragamnya mata pelajaran yang harus diajarkan dan sekaligus sebagai tuntutan kebijakan, tuntutan untuk berkualitas pada pendidikan Islam yang diajarkan disatu sisi, dan disisi lain pada mata pelajaran umum. Hal lain kualitas tenaga guru (tenaga pendidik) yang kualitasnya rendah, manajemen pengelolaan madrasah kurang professional, dan sarana pendidikan yang kurang memadai, kuantitas siswa mayoritas latarbelakang ekonomi keluarga kurang mampu. Berikut penganggaran pendidikan mengalami tendensi dikotomi jika dibandingkan dengan sekolah umum. Demikian kebijakan yang kurang adil dan kecenderungan diskriminatif masih menyisakan pertanyaan serius diberbagai kalangan.

Lembaga pendidikan yang berada dibawah naungan Kementerian Agama ini mayoritasnya adalah madrasah yang berstatus swasta, jika dibandingkan dengan madrasah negeri pun mengalami dikotomi. Meskipun pada awalnya, mayoritasnya madrasah pada semua jenjang adalah berstatus swasta, bahkan madrasah yang berstatus negeri pada awalnya adalah madrasah

${ }^{27}$ Azyumardi Azra, Paradigma Baru Pendidikan Nasional, Rekonstruksi dan Demokratisasi, (Jakarta, Kompas Buku, 2002), hlm. 88.

${ }^{28}$ Mahmud Arif, Panorama Pendidikan Islam di Indonesia. Sejarah, Pemikiran, dan Kelembagaan, Yogyakarta: Idea Press, 2009), hlm. 83-84. 


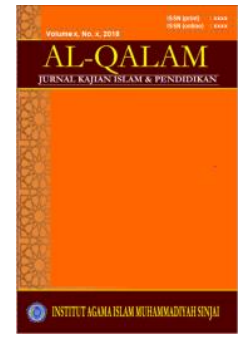

\section{AL-QALAM}

Jurnal Kajian Islam \& Pendidikan

Volume 07 No 022015

ISSN (print) : 1858-4152

ISSN (online) : 2715-5684

Homepage : http://journal.iaimsinjai.ac.id/index.php/al-qalam

swasta yang dikonversi menjadi madrasah negeri. ${ }^{29}$ Kerumitan yang terjadi pada system pendidikan Islam ini menyebabkan madrasah seolah hanya jalan ditempat. Disisi lain terjadi pula kerumitan dalam pendidikan di Indonesia, yaitu lembaga pendidikan umum dan lembaga pendidikan Islam (madrasah) dengan kelembagaan pusat yang berbeda sejak era Orde Baru, pendidikan kita mengalami system dualistik kelembagaan pusat sebagai payungnya. Sekolah umum yang berada dibawah naungan Kementerian Pendidikan dan Kebudayaan dan madrasah berada dibawah naungan Kementerian Agama.

Kendati banyak persoalan yang muncul dalam penyelenggaraan madrasah, dewasa ini lembaga pendidikan Islam madrasah hadir dan familiyar serta menjadi salah satu pilihan elit masyarakat, karena madrasah yang murah dalam hal pembiayaan serta dapat dijangkau oleh banyak kalangan, hal ini makin mampu beriringan dalam ranah global terlebih peranannya dalam pemberantasan buta huruf dalam rangka upaya pencerdasan generasi bangsa. Di beberapa daerah di tanah air tidak dapat dipungkiri bahwa eksistensi madrasah hingga hari ini dinilai telah dapat menempati posisi setaraf dengan pendidikan formal lainnya terkait output yang dihasilkan dalam hal kualitas baik dari segi ilmu-ilmu terapan terlebih ilmu keislaman sebagai ciri khasnya.

\section{Pengembangan Madrasah; Wacana Strategi Reposisi}

Pengembangan madrasah sebagai lembaga pendidikan Islam perlu menjadi perhatian serius bagi semua kalangan guna tercapainya mutu pendidikan yang dicita-citakan sesuai tujuan pendidikan nasional disamping tujuan pendidikan Islam. Menurut Abuddin Nata dalam Imron Fauzi, bahwa pengembangan tersebut terkait dengan upaya memperbaiki, meningkatkan, dan memajukan suatu kegiatan dari keadaan yang kurang maju kepada keadaan yang lebih maju. dalam bidang pendidikan, pengembangan dapat dilakukan pada seluruh komponen pendidikan, antara lain pengembangan

${ }^{29}$ Ali Maksum, Pembaharuan Sistem Pendidikan Pada Madrasah, dalam Nizamia, (Surabaya, Fakultas Tarbiyah IAIN Sunan Ampel, 2005), Vol. 8 Nomor 1, hlm.38. 
mutu sumber daya manusia (khususnya guru), pengembangan kurikulum dan materi pelajaran, pengembangan proses belajar mengajar, pengembangan sarana prasarana dan sebagainya. ${ }^{30}$

Hal ini dinilai penting menjadi perhatian serius sehingga tetap eksis dan mengejar ketertinggalan, namun usaha tersebut perlu dipahami bahwa madrasah juga memiliki faktor penghambat dan pendukung, disinilah para pengelolah lembaga pendidikan madrasah perlu berjuang maksimal untuk mengembangkannya. Eko Susilo mengutip A. Fatta Yasin dalam bukunya Dimensi-Dimensi Pendidikan, mengemukakan faktor penghambat dan faktor pendukung perkembangan madrasah yaitu: ${ }^{31}$

1. Faktor penghambat:
a. Sistem manajemen dan etos kerja yang rendah
b. Kualitas dan kuantitas guru yang kurang memadai
c. Kurikulum yang tidak efektif
d. Sarana fisik dan fasilitas yang masih belum cukup

2. Faktor pendukung:

a. Merespon kebutuhan peserta didik, kemajuan ilmu dan tekhnologi, kebutuhan pembangunan nasional dan relevan dengan pandangan hidup bangsa serta ajaran agama masyarakat.

b. Sistem pendidikan yang dikembangkan adalah mampu menumbuhkan peserta didik sesuai dengan kecenderungan sehingga dapat bekerja untuk menghidupi dirinya dan keluarganya tersebut.

c. Pemberian pedoman moral sesuai dengan keyakinan dan tantangan zamannya sehingga peserta didik mampu hidup hormat dan disegani dalam tata pergaulan hidup bersama ditengah-tengah masyarakat.

d. Mampu mengembangkan keterampilan dan budi pekerti luhur peserta didik sesui dengan agama, kepercayaan dan budayanya. Sehingga dapat menghadirkan peserta didik untuk dapat hidup ditengah

\footnotetext{
hlm.66-67.

${ }^{31}$ Eko Susilo, dkk. Politik., hlm.304-305.
}

${ }^{30}$ Imron Fauzi, Manajenen Pendidikan ala Rasulullah, (Yogyakarta: Ar-Ruzz Media, 2012), 


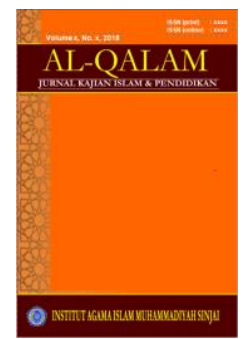

\section{AL-QALAM}

Jurnal Kajian Islam \& Pendidikan

Volume 07 No 022015

ISSN (print) : 1858-4152

ISSN (online) : 2715-5684

Homepage : http://journal.iaimsinjai.ac.id/index.php/al-qalam

masyarakat yang dapat mendatangkan manfaat, rasa aman, dan kepercayaan serta memberikan harapan-harapan baru bagi masyarakatnya.

Prinsip pengembangan madrasah tidak hanya terkait pada persoalan mutu, kurikulum dan sarana prasarana, jika esensi SKB tiga Menteri disisi lain memberikan penyetaraan derajat kelulusan dan persamaan kurikulum dengan sekolah umum yang telah diberlakukan selama ini (baik materi maupun jumlah jam), maka hingga kini masih muncul pertanyaan diberbagai kalangan, mengapa madrasah masih belum begitu maksimal akan memainkan peranannya secara praksis-aplikatifnya? Apakah pemerintah masih setengah hati memberikan layanan yang memadai, baik dari segi sarana-prasarana maupun anggaran pendidikan?, maka hal ini dapat diidentifikasi sekurangkurangnya ada tiga penyebab yaitu:

1) Madrasah dalam praktek pengelolaannya sebagian besar (khususnya madrasah swasta) belum tangani sepenuhnya secara professional oleh orang dibidangnya sehingga hal ini belum memberikan nilai jual dan nilai tawar bagi masyarakat pada umumnya, kebanyakan madrasah masih seolah tertutup dengan informasi perkembangan pendidikan dan globalisasi, hal ini dikarenakan masih adanya asumsi bahwa era globalisasi (tekhnologi informasi) dapat menggeser nilai-nilai historisnya yang masih kental dengan prinsip-prinsip Islam, disini penting dilakukan pengintegrasian antara ilmu agama sebagai dasar historisnya dengan teknologi informasi sebagai langkah memodernisasi kemajuan lembaga pendidikan Islam madrasah-swasta yang masih terbelakang.

2) Perhatian pemerintah dalam hal pengelolaan pendidikan secara nasional masih terpecah dan disinyalir tidak fokus karena masih memainkan peran masing-masing baik sekolah umum di bawah naungan Kementerian Pendidikan dan Kebudayaan, maupun sekolah (madrasah) dibawah naungan Kementerian agama. Hingga kini banyak isu yang berkembang dikalangan akademisi maupun praktisi pendidikan sekaligus tawaran akan 
penyamaan hak antara madrasah dan sekolah umum baik dari segi penganggaran (pembiayaan) yang disalurkan pemerintah maupun system pengelolaan dalam satu kebijakan pusat, dengan pengertian bahwa yang terkait pendidikan secara keseluruhan perlu dibawah naungan satu Departemen yakni khusus Departemen Pendidikan dan Kebudayaan, sedangkan untuk Departemen Agama fokus pada wilayah kebijakannya yakni keagamaan. Kendati tawaran penyamaan pengelolaan satu kebijakan terpusat tersebut, melakukannya bukanlah hal yang mudah. Dibutuhkan analisis yang mendalam dari latarbelakang historisnya hingga kesiapan semua pihak dalam mengambil peran untuk menyukseskan pendidikan serta konsekwensi yang akan ditimbulkan.

3) Pada sisi lain hingga kini kenyataannya citra kepercayaan masyarakat mulai menurun disebabkan karena mutu lulusan dalam persaingan kerja, kurangnya profesionalisme pengelolaan administrasi madrasah, etos kerja pegawai yang rendah, maupun system manajemen yang tidak mengalami pembaruan. Disini diperlukan peranan unsur pengelolah (kepala sekolah dan guru) untuk mengambil langkah serta membangun citra kepercayaan masyarakat, sehingga kesan yang timbul tidak hanya pada tingkat pembayaran yang dikeluarkan oleh orang tua siswa melainkan prestasi yang mampu bersaing.

Berangkat dari hal diatas, adanya konsep desentralisasi pendidikan ${ }^{32}$ (otonomi sekolah) maka reposisi dan pengembangan madrasah perlu dukungan pemerintah daerah dan segenap pihak. Desentralisasi pendidikan

${ }^{32}$ Lihat, Landasan yuridis desentralisasi ini termuat dalam Undang-undang Otonomi Daerah No. 22 Tahun 1999 pada Bab I pasal 1 e dan h. Tambahan Lembaran Negara Republik Indonesia Nomor 3839, hlm.3. Desentralisasi pendidikan disini dapat diartikan terjadinya pelimpahan kekuasaan dan kewenangan yang lebih luas kepada daerah untuk membuat perencanaan dan mengambil keputusannya sendiri dalam mengatasi permasalahan yang dihadapi dibidang pendidikan. Abdul Halim, Bunga Rampai Manajemen Keuangan Daerah, (Yogyakarta:YKPN,2001), hlm. 12. Selanjutnya menurut Ali Riyadi, Desentralisasi pendidikan sesungguhnya memberikan keleluasaan kepada lembaga pendidikan dalam setiap aktifitas kelembagaan dan kependidikannya. Ali Riyadi, Politik Pendidikan, Menggugat Birokrasi Pendidikan Nasional, (Yogyakarta: Ar-Ruzz Media, 2006), hlm. 231. 


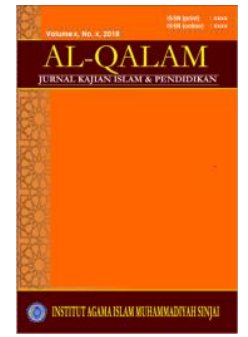

\section{AL-QALAM}

Jurnal Kajian Islam \& Pendidikan

Volume 07 No 022015

ISSN (print) : 1858-4152

ISSN (online) : 2715-5684

Homepage : http://journal.iaimsinjai.ac.id/index.php/al-qalam

khususnya pendidikan madrasah adalah kewenangan yang diberikan kepada daerah dalam hal ini Kementerian Agama dan pengelolah madrasah untuk membuat suatu strategi pengembangan (membuat perencanaan dan mengambil keputusan) terkait system dan manajemen madrasah yang bermutu guna memenuhi tuntutan dan kebutuhan masyarakat seiring dengan perkembangan globalisasi tanpa meninggalkan asas-asas keislaman sebagai ciri khas pendidikan madrasah tersebut.

Beragam paradigma baru yang muncul dibidang pendidikan hal ini mengindikasikan masyarakat menantikan pentingnya pengembangan pendidikan khususnya pengembangan madrasah diera kompetisi global, langkah penting yang dapat menjadi catatan bagi segenap komponen yang terlibat pengelolaan pengembangan madrasah adalah kebijakan pendidikan yang demokratis. Pengelolaan pendidikan secara demokratis ini dapat dikatakan sebagai salah satu strategi yang tepat masa kini. Demokratisasi disini sebagai contoh dapat dimaksudkan Manajemen Berbasis Madrasah (MBM), melalui MBM pendidikan dimadrasah dapat dipahami sebagai langkah menjawab kebutuhan masyarakat sesuai kondisi yang dialami, baik secara kultural, adat-istiadat, terlebih persoalan ilmu keagamaan dan pengetahuan umum. Said Agil Husin Al-Munawar memberikan pandangan bahwa dengan MBM ini berarti akan mengembalikan peran madrasah yang sesungguhnya, sebagaimana visi dan misi pertama madrasah didirikan. ${ }^{33}$

Keberadaan unsur-unsur kebebasan dalam aktivitas pendidikan merupakan kunci atau fondasi terwujudnya demokratisasi pendidikan Islam. Demokratisasi pendidikan Islam sendiri merupakan upaya-upaya yang menciptakan pendidikan Islam yang berbasis dari tekanan-tekanan dan pemaksaan serta bentuk-bentuk aktivitas pendidikan yang serba sangat birokratis, hirarkis, sentralistis dan elitis. ${ }^{34}$ Dalam hal ini kebijakan

${ }^{33}$ Said Agil Husin Al-Munawar, Aktualisasi Nilai-Nilai Qur'an dalam Sistem Pendidikan Islam, edt. Ummi Kalsum dan Syahrini Tambak, (Ciputat: PT. Cirutat Press, 2005), hlm. 200.

${ }^{34}$ Adapun demokratisasi pendidikan dalam pandangan para pemikir pendidikan Islam di Indonesia berawal dari kritik mereka terhadap system pendidikan Islam tradisional seperti apa 
pendidikan dan pengembangan madrasah sangat dipengaruhi adanya demoraktisasi. format alternatif yang berkenaan dengan kebijakan demokratisasi patut dijadikan pertimbangan sebagai proses pengembangan madrasah.

Oleh karena itu menurut hemat penulis, pengembangan madrasah sebagai strategi reposisi menuju perkembangan mutu diera kompetitif globalisasi masa kini adalah: (1) Perlunya integratif dikalangan pemerintah dengan pengelolah pendidikan di madrasah sangat berperan dalam upaya menumbuhkan kesadaran untuk kemajuan entitas budaya lokal madrasah yang bercirikhaskan Islam religius. Pemerintah penting membuka diri dan memiliki keberanian untuk menumbuhkembangkan pendidikan Islam khususnya madrasah. Namun kelemahan disisi lainnya adalah menimbulkan kesenjangan mutu pendidikan antar daerah. (2) Peranan masyarakat yang sadar pendidikan sangat penting, partisipasi terhadap pendidikan Islam tak hanya mengarahkan anak didik untuk belajar pada pendidikan formal (madrasah) namun bimbingan orang tua sebagai utama dikalangan keluarga paling berpengaruh, demikian pula masyarakat Islam mayoritas patut diperhitungkan dalam mengambil peran baik dari dukungan finansial yang memadai untuk menunjang proses pendidikan di madrasah. (3) Diera kompetitif madrasah swasta penting membangun system jaringan kerja dan sumber pembiayaan tambahan (networking and funding) dengan pihak-pihak atau lembaga yang memiliki perhatian terhadap pendidikan, baik dalam ranah lokal, nasional maupun internasional. (4) Pentingnya pemerintah pusat berlaku lebih adil tanpa mendiskriminasikan lembaga pendidikan Islam dibawah pengelolaan Kementerian Agama dengan lembaga pendidikan umum yang berada dibawah

yang telah disampaikan oleh Syafii Maarif. Ia mengatakan bahwa system pendidikan tradisional yang kurang atau lemah pengalaman berdemokrasi. Demokrasi pendidikan yang dibangun oleh para pemikir pendidikan Islam merupakan upaya untuk membangun dasar-dasar persamaan, kebebasan, keadilan, keterbukaan, dan anti diskriminatif. Saleh Subagja, Gagagsan Liberalisasi Pendidikan Islam, (Konsep Pembebasan dalam Pembelajaran Pendidikan Islam), (Malang, Penerbit Madani, 2010), hlm.188-189. 


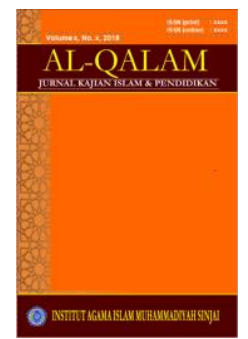

\section{AL-QALAM}

Jurnal Kajian Islam \& Pendidikan

Volume 07 No 022015

ISSN (print) : 1858-4152

ISSN (online) : 2715-5684

Homepage : http://journal.iaimsinjai.ac.id/index.php/al-qalam

pengeloaan Kementerian Pendidikan dan Kebudayaan. (5) Lembaga pendidikan madrasah perlu melakukan peningkatan layanan pendidikan yang mencakup seluruh siswa tanpa adanya perbedaan latar belakang sosial maupun ekonomi, mempertahankan kualitas pendidikan yang telah tercapai dan melakukan upaya pencegahan siswa putus sekolah. (6) Pengembangan bakat dan kreatifitas siswa dengan menciptakan lembaga organisasi yang dapat mengembangkan minat profesionalnya. (7) Perlunya madrasah merumuskan, menetapkan serta mensosialisasikan kepada publik mengenai visi dan misi madrasah yang dimiliki serta jelas yang berorientasi tujuan utama pendidikan Islam dan mengarah pada nilai kebutuhan masa depan masyarakat yang siap menghadapi perkembangan globalisasi. (8) Pentingnya madrasah meningkatkan penguasaan dan keahlian yang berbasis sains dan tekhnologi. (9) pendidik adalah pelaku dalam proses transfer of knowledge, motifator dan inspirator, maka diperlukan perekrutan guru-pendidik yang betul-betul siap dan memiliki kompetensi dibidangnya serta terbukti akan kualitasnya. (10) Pentingnya penerapan dan penekanan terhadap peserta didik dalam penguasaan bahasa dalam hal bahasa asing, penting menjadi modal sekaligus wawasan global untuk mampu bersaing dalam percaturan pembangunan nasional. (11) Pemerintah-pemegang kebijakan pendidikan, penting merumuskan dan menetapkan kebijakan yang betul-betul berpihak dan menguntungkan semua pihak yang terlibat baik pengelolah pendidikan, pegawai, guru, peserta serta masyarakat.

Langkah-langkah pengembangan tersebut sebagai wacana strategi reposisi tentunya dapat dilihat dari aspek politik, sosial, ekonomi, budaya dan aspek teknis. Pola pengembangan pendidikan Islam madrasah yang bersifat makro ini menuntut kesadaran, kemauan dan kerja keras serta komitmen yang tinggi meskipun melakukannya dipengaruhi pasang surutnya kebijakan politik pemerintah.

\section{KESIMPULAN}


Madrasah sebagai lembaga pendidikan Islam yang telah lahir sejak abad ke empat hijriyah membawa misi pendidikan bagi umat Islam pada umumnya, hingga keberadaan madrasah di Indonesia sebagai embrio yang lahir dari rahim pesantren pada abad ke-20 sebagai bentuk kebangkitan pendidikan Islam di tanah air. Madrasah sebagai sekolah yang bercirikan Islam merupakan tahapan dan pengembangan dari pesantren sejak pra kemerdekaan, kelahirannya yang dilatarbelakangi oleh kurang memenuhinya kebutuhan masyarakat terkait lembaga pendidikan keislaman madrasah-persekolahan dan kemampuan pragmatis demikian pula sebagai respon kebijakan pendidikan terhadap pemerintah Belanda dalam menerapkan pendidikan sekuler.

Perkembangan madrasah pada era Orde Lama yang kurang mendapatkan ruang dan perhatian pemerintah namun ketika pada Orde Baru telah melahirkan beberapa kebijakan terkait pengembangan madrasah ini seperti lahirnya Surat Keputusan Bersama tiga Menteri yang terkait penyetaraan dan perubahan mendasar strukturalnya. Hingga memasuki era reformasi peran madrasah dalam membina generasi bangsa Indonesia tetap diperhitungkan dengan kebijakan pemerintah terkait lahirnya UUSPN No. 20 Tahun 2003 tentang system pendidikan nasional yang memberikan pengakuan tanpa dikriminasi dalam pendidikan nasional. Kendati hingga sekarang pendidikan madrasah masih menuai problematika yang tak kian surut dengan kebijakan pemerintah hingga kini.

Eksistensi madrasah hingga kini walau peranannya yang demikian besar seolah tak sebanding dengan kebijakan pemerintah terhadap madrasah sebagai bagian dari pendidikan nasional selalu diwarnai dengan ragam polemiknya baik dari segi mutu, kurikulum, kebijakan pemerintah dalam hal penganggaran dan sebagainya. Hal ini menuntut perbaikan dari berbagai pihak untuk mengembangkannya sehingga dapat menempatkan diri sebagai lembaga pendidikan yang terkemuka baik dalam ciri khas keislamannya maupun dalam bidang pengetahuan umum di Indonesia. Langkah reposisi dan pengembangan diharapkan dapat membawa pendidikan Islam madrasah dalam era kompetitif global kini, dengan mengambil bagian dari wacana solutif itu maka pada 


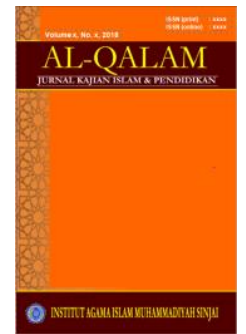

\section{AL-QALAM}

Jurnal Kajian Islam \& Pendidikan

Volume 07 No 022015

ISSN (print) : 1858-4152

ISSN (online) : 2715-5684

Homepage : http://journal.iaimsinjai.ac.id/index.php/al-qalam

pembahasan di atas beberapa strategi pengembangan madrasah dapat menyentuh sebagai analisis strategis. Olehnya kebijakan politik pemerintah yang betul-betul berpihak pada pendidikan sangat berperang dalam mendukung tercapainya pengembangan madrasah kini dan masa yang akan datang.

\section{DAFTAR PUSTAKA}

Al-Munawar, Husin, Agil, Said, Aktualisasi Nilai-Nilai Qur'an dalam Sistem Pendidikan Islam, edt. Ummi Kalsum dan Syahrini Tambak, (Ciputat: PT. Cirutat Press), 2005.

Arif, Mahmud, Panorama Pendidikan Islam di Indonesia. Sejarah, Pemikiran, dan Kelembagaan,(Yogyakarta: Idea Press), 2009.

Arif, Mahmud, Sketsa Sejarah, Geliat, dan Dinamika Peran Madrasah dalam Merespon Tantangan Pendidika Islam (Dilema Madrasah dalam Kancah Pendidikan dan Peran Kontributif Madrasah Berbasis Pesantren). Edt. Prof. Dr. Nizar Ali, M.Ag dan Dr. H. Sumedi, M.Ag. dalam Ontologi Pendidikan Islam, (Yogyakarta, Program Pascasarjana UIN Sunan Kalijaga kerjasama Penerbit Idea Press), 2010.

Azra, Azyumardi, Paradigma Baru Pendidikan Nasional, Rekonstruksi dan Demokratisasi, (Jakarta, Kompas Buku), 2002.

Fauzi, Imron, Manajenen Pendidikan ala Rasulullah, (Yogyakarta:Ar-Ruzz Media), 2012.

Gunawan, Ary, H, Kebijakan Kebijakan Pendidikan, (Jakarta: Rineka Cipta), 1995.

Halim, Abdul, Bunga Rampai Manajemen Keuangan Daerah, (Yogyakarta: YKPN), 2001.

Langgulung, Hasan, Asas-Asas Pendidikan Islam, (Jakarta: Al-Husna Zikra), 2000.

Machali, Imam, dan Hidayat, Ara, Pengelolaan Pendidikan (Konsep, Prinsip, dan Aplikasi dalam Mengelolah Sekolah dan Madrasah), (Yogyakarta: Kaukaba), 2012. 
, Kebijakan Pendidikan Islam dari Masa Ke Masa, Dari Kebijakan Diskriminatif Menuju Kebijakan Berkeadilan, dalam Website: http://www.imammachali.com.

Maksum, Ali, Pembaharuan Sistem Pendidikan Pada Madrasah, dalam Nizamia, Surabaya, Fakultas Tarbiyah IAIN Sunan Ampel, 2005, Vol. 8 Nomor 1.

Maksum, Madrasah Sejarah dan Perkembangannya, (Jakarta, Logos Wacana Ilmu), 1999.

Mas'ud, Abdurrachman, dkk, Dinamika Pesantren dan Madrasah, edt. Ismail SM dkk, (Semarang: Fakultas Tarbiyah IAIN Walisongo bekerja sama Pustaka Pelajar, Yogyakarta), 2002.

Hasyim, Yusuf, Kebijakan Otonomi Daerah dan Implikasinya Terhadap Pendidikan Madrasah, dalam Website: http://gurubangsaku.wordpress.com.

Retnoningsih, Ana, dan, Suharso, Kamus Besar Bahasa Indonesia, Edisi Lux, (Semarang: CV. Widia Karya), 2011.

Riyadi, Ali, Politik Pendidikan, Menggugat Birokrasi Pendidikan Nasional, (Yogyakarta: Ar-Ruzz Media), 2006.

Steenbrink, A. Karel, Pesantren Madrasah Sekolah (Pendidikan Islam dalam Kurun Moderen), (Jakarta: Darma Aksara Perkasa), 1986.

Subagja, Saleh, Gagagsan Liberalisasi Pendidikan Islam, (Konsep Pembebasan dalam Pembelajaran Pendidikan Islam), (Malang, Penerbit Madani), 2010.

Susilo, Eko, dkk. Politik Pendidikan Nasional, edt. Syahridlo dan Sutarman, Yogyakarta, Kopertais Wilayah III Daerah Istimewa Yogyakarta UIN Sunan Kalijaga, 2011.

Syalaby, Ahmad, Sedjarah Pendidikan Islam, Ter. Muchtar Yahya dan Sanusi Latief, (Jakarta: Bulan Bintang), t.t,.

Toto Suharto, Abdullah Idi, dan, Revitalisasi Pendidikan Islam, (Yogyakarta: Tiara Wacana), 2006.

Undang-Undang Republik Indonesia No, 22 Tahun 1999 Tentang Pemerintahan Daerah, (dalam pdf), Tambahan Lembaran Negara Republik Indonesia Nomor 3839. 


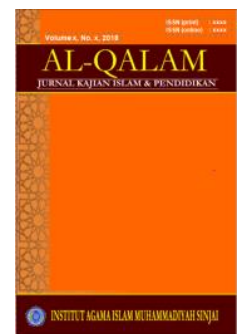

\section{AL-QALAM}

Jurnal Kajian Islam \& Pendidikan

Volume 07 No 022015

ISSN (print) : 1858-4152

ISSN (online) : 2715-5684

Homepage : http://journal.iaimsinjai.ac.id/index.php/al-qalam

Undang-Undang Republik Indonesia No. 20 Tahun 2003 Tentang Sistem Pendidikan Nasional, (dalam pdf), (Tambahan Lembaran Negara Republik Indonesia Nomor 4301), diundangkan di Jakarta pada tanggal 8 Juli 2003.

Yunanto. S, et.al, Pendidikan Islam di Asia Tenggara dan di Asia Selatan (Keragaman, Permasalahan dan Strategi), (Jakarta: The RIDEP Institut kerjasama Friedrich Ebert Stiftung), 2005. 